\section{Commentary: Another step forward ischemic mitral regurgitation comprehension}

\author{
Michele Di Mauro, MD, PhD, MSc, ${ }^{\text {a,b }}$ \\ Stefano Guarracini, $\mathrm{MD}, \mathrm{PhD}{ }^{\mathrm{b}}$ \\ Donato Capuzzi, MD, ${ }^{\mathrm{b}}$ and \\ Antonio M. Calafiore, $\mathrm{MD}^{\mathrm{c}}$
}

Ischemic mitral regurgitation (IMR) has been considered easily to treat, for years; indeed, the main surgical approach has been restrictive mitral annuloplasty (RMA), addressing just one of the actors involved in the pathophysiologic pathway leading from acute myocardial infarction to IMR. ${ }^{1,2}$ Unfortunately, IMR turned out to be more technical demanding, so the results of RMA have been scarce so far. ${ }^{3-5}$

In an attempt to improve the durability of mitral valve repair for IMR, many study groups are trying to better elucidate the right mechanisms underlying this disease. Recently, we published some articles ${ }^{6,7}$ where even leaflets and chords postischemic modifications are summarized with relative mechanisms, further supporting the need for valvular and subvalvular approaches to improve outcomes. In this scenario, the animal-model study proposed by the Gorman Cardiovascular Research Group ${ }^{8}$ represents another step toward IMR comprehension. The great strength of this study is having employed a multimodal imaging approach to better understand the dynamics of mitral subvalvular apparatus in IMR. Recently, technology of

\footnotetext{
From the ${ }^{\mathrm{a}}$ Cardio-Thoracic Surgery Unit, Heart and Vascular Centre, Maastricht University Medical Centre (MUMC), Cardiovascular Research Institute Maastricht (CARIM), Maastricht, The Netherlands; ${ }^{\mathrm{b}}$ Department of Cardiovascular Disease, "Pierangeli" Hospital, Pescara, Italy; and ${ }^{\mathrm{c}}$ Department of Cardiac Surgery, Gemelli Molise, Campobasso, Italy.

Disclosures: The authors reported no conflicts of interest.

The Journal policy requires editors and reviewers to disclose conflicts of interest and to decline handling or reviewing manuscripts for which they may have a conflict of interest. The editors and reviewers of this article have no conflicts of interest.

Received for publication Nov 24, 2020; revisions received Nov 24, 2020; accepted for publication Nov 27, 2020; available ahead of print Dec 27, 2020.

Address for reprints: Michele Di Mauro, MD, PhD, MSc, Cardio-Thoracic Surgery Unit, Heart and Vascular Centre, Maastricht University Medical Centre (MUMC), Cardiovascular Research Institute Maastricht (CARIM), P. Debyelaan 25,6202 AZ Maastricht, The Netherlands (E-mail: mdimauro1973@gmail.com). JTCVS Open 2021;5:61-2

2666-2736

Copyright $(\underset{2}{ } 2020$ The Authors. Published by Elsevier Inc. on behalf of The American Association for Thoracic Surgery. This is an open access article under the CC BY-NCND license (http://creativecommons.org/licenses/by-nc-nd/4.0/).

https://doi.org/10.1016/j.xjon.2020.11.012
}

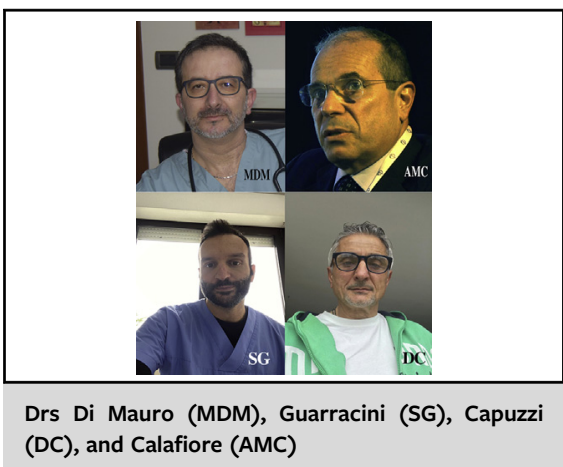

CENTRAL MESSAGE

The study by Aly and colleagues clearly demonstrates that ischemic mitral regurgitation is a complex disease that deserves valvular and subvalvular surgical approaches.

cardiac imaging has advanced, and patients with cardiovascular disease have become increasing more complex. This has led to the integration of several different imaging techniques with a single aim: to clarify the mechanisms at the basis of the disease to guide treatment and predict prognosis. ${ }^{9}$ Aly and coworkers ${ }^{8}$ with this approach are able to demonstrate anterior leaflet area increment, reduction of posteromedial papillary muscle volume, and that the latter muscle mainly displaces horizontally and outward along the intercommissural axis. These findings confirm as IMR, especially high-grade, is the result of an unbalanced process starting after myocardial infarction. ${ }^{6,7,10}$ With this in mind, lone RMA cannot be the unique choice of treatment for IMR; valvular and subvalvular approaches have to deemed necessary.

\section{References}

1. Braun J, van de Veire NR, Klautz RJ, Versteegh MI, Holman ER, Westenberg JJ, et al. Restrictive mitral annuloplasty cures ischemic mitral regurgitation and heart failure. Ann Thorac Surg. 2008;85:430-6.

2. Gelsomino S, Lorusso R, De Cicco G, Capecchi I, Rostagno C, Caciolli S, et al. Five-year echocardiographic results of combined undersized mitral ring annuloplasty and coronary artery bypass grafting for chronic ischaemic mitral regurgitation. Eur Heart J. 2008;29:231-40.

3. McGee EC, Gillinov AM, Blackstone EH, Rajeswaran J, Cohen G, Najam F, et al. Recurrent mitral regurgitation after annuloplasty for functional ischemic mitral regurgitation. J Thorac Cardiovasc Surg. 2004;128 916-24.

4. Michler RE, Smith PK, Parides MK, Ailawadi G, Thourani V, Moskowitz AJ, et al. Two-year outcomes of surgical treatment of moderate ischemic mitra regurgitation. N Engl J Med. 2016;374:1932-41. 
5. Onorati F, Rubino AS, Marturano D, Pasceri E, Mascaro G, Zinzi S, et al. Midterm echocardiographic results with different rings following restrictive mitral annuloplasty for ischaemic cardiomyopathy. Eur J Cardiothorac Surg. 2009; 36:250-60.

6. Calafiore AM, Totaro A, Paparella D, Gaudino M, Prapas S, Mick SL, et al. Mimicking natural mitral adaptation to ischaemic regurgitation: a proposed change in the surgical paradigm. Eur J Cardiothorac Surg. 2020;58:35-9.

7. Calafiore AM, Totaro A, Testa N, Sacra C, Castellano G, Guarracini S, et al. The secret life of the mitral valve. J Card Surg. 2021;36:247-59.
8. Aly AH, Saito Y, Bouma W, Pilla JJ, Pouch AM, Yushkevich PA, et al. Multimodal image analysis and subvalvular dynamics in ischemic mitral regurgitation. J Thorac Cardiovasc Surg Open. 2021;5:48-60.

9. Capoulade R, Piriou N, Serfaty JM, Le Tourneau T. Multimodality imaging assessment of mitral valve anatomy in planning for mitral valve repair in secondary mitral regurgitation. J Thorac Dis. 2017;9(suppl 7): S640-60.

10. Kim K, Kaji S, An Y, Yoshitani H, Takeuchi M, Levine RA, et al. Mechanism of asymmetric leaflet tethering in ischemic mitral regurgitation: $3 \mathrm{D}$ analysis with multislice CT. JACC Cardiovasc Imaging. 2012;5:230-2. 